\title{
Academic Mentoring Relationship Communication Processes and Participant-Reported Effectiveness
}

\author{
Shannon A. Scielzo \\ University of Texas at Arlington \\ Ajal Patel \\ University of Texas at Arlington \\ Kimberly A. Smith-Jentsch \\ University of Central Florida
}

\begin{abstract}
The current study attempted to broaden our understanding of communication processes that occur in academic mentoring relationships. Using the Linguistic Inquiry Word Count (LIWC) program, it was found that mentors and protégés would mirror one another's communications. Moreover, mentors and protégés reacted differently in regards to their perceptions of what occurred during the course of the relationship relative to the different communication indicators. For example, mentor and protégé emotion-related communications were important for protégés, whereas cognitive-related communications were important for mentors. Assent communications were positively perceived by protégés, whereas they were negatively perceived by mentors.
\end{abstract}

\section{INTRODUCTION}

The transition period for incoming university students can be tumultuous, as they need to learn new study skills, new social norms, rules, general information about the university and their classes, possibly having to acclimate to their first time away from their family, and learning to deal with roommates, along with other obstacles. One mechanism that has been proposed to help ameliorate the intensity of such a transition is the use of formal mentoring relationships (Burney, Celeste, Davis Johnson, Klein, Nordal, \& Portnoy, 2009; Brown, Daly, \& Leong, 2009; Campbell, 2007; D’Abate \& Eddy, 2008; Garone, 2009).

\section{Potential Benefits of Mentoring Relationships}

Many individuals have traced the concept of 'mentoring' to having origins back into the mid- to late15th century (Roberts, 2000). These relationships have been found to be associated with a myriad of positive outcomes for protégés, such as higher rates of promotion, higher incomes, higher career and job satisfaction, and increased knowledge (Allen, Eby, Poteet, Lentz, \& Lima, 2004; Chao, Walz, \& Gardner, 1992; Durkin \& Main, 2002; Fagenson, 1989; Koberg, Boss, Chappell, \& Ringer, 1994). Furthermore, mentoring relationships have been advocated as a means for facilitating the acclimation of minorities, such as in underrepresented areas (Alvarez, Blume, Cervantes, \& Thomas, 2009; Evans \& Cockley, 2008; 
Nguyen, Huynh, \& Lonergan-Garwick, 2007). Yet, although present for this substantial period of time, there seems to be little understanding regarding the dynamics that occur during the course of mentoring relationships (Johnson, 2008), and subsequently, how to maximize the effectiveness of such relationships. Furthermore, examination of the results of the numerous studies that have been conducted demonstrate that there are many gaps yet to be filled in our understanding of subjective perceptions of mentoring relationship success, and how mentor relationship processes relate to these subjective indicators. This study attempts to further our understanding in these areas.

\section{Communication Reciprocity}

Given that a mentoring relationship is, in fact, an interpersonal relationship in which individuals must communicate, respond to one another, and share information about oneself, it stands to reason that individuals that are effective in such relationships should modify their own behaviors in regards to their partner's. In support of this notion, a substantial amount of research in the social psychological and communication areas have found that individuals tend to reciprocate in relationships, and that reciprocity is associated with positive relationship outcomes (e.g., Bernstein, 1967; Derlega, Wilson, \& Chaikin, 1976; Hendrickson \& Goei, 2009; Kantar Agliata \& Renk, 2009; Powell \& O’Neal, 1997). Furthermore, vicarious learning theory (Bandura, 1977) proposes that individuals learn from observing others. Thus, it seems likely that individuals will likely learn from their partners in mentoring relationships (which in many instances are likely fairly novel contexts for both mentors and protégés) and subsequently display the same behaviors. As a result, it was hypothesized that mentors and protégés would mirror each others' communication behaviors; specifically, individuals will undertake more communication behaviors when their partners undertake these behaviors.

In an attempt to obtain an unbiased indicator of communication processes for examining reciprocity, the Linguistic Inquiry and Word Count (LIWC; Pennebaker, Chung, Ireland, Gonzales \& Booth, 2007) text analysis program was selected for coding of transcripts. This program identifies several grammatical, linguistic, and psychological features of electronic communication transcripts. The LIWC has previously been used in studies in numerous contexts (e.g., Pennebaker, 1997; Pennebaker \& Francis, 1996), demonstrating construct and criterion related validity. For example, it has been found to be successful at identifying emotional expression (O'Carroll Bantum \& Owen, 2009), depression (Vanheule, Desmet \& Meganck, 2009), and has been used for various purposes such as monitoring progress for individuals undergoing therapy (Stephenson, Laszlo, Ehmann, Lefever, Lefever, 1997).

\section{Psychosocial and Academic/Career Support Functions}

Researchers often attempt to measure the quality of mentoring relationships by assessing mentors' and protégés' perceptions of the mentoring functions that were provided during the course of the relationship. Kram and Isabella (1985) proposed that two types of functions are provided in mentoring relationships: psychosocial and career support functions. Psychosocial functions refer to those functions that address more psychological and/or socially related issues that an individual might face, such as friendship, confirmation, role modeling, acceptance, and counseling, whereas career development/support functions tend to focus on more task/work/career related issues, such as coaching, sponsorship, protection, providing challenging assignments, and increasing exposure and visibility.

Numerous outcomes have been found to be associated with these mentoring functions. For example, a meta-analysis conducted by Allen, Eby, Poteet, Lentz, and Lima (2004) found that perceived career support functions were related to compensation and promotion for protégés. Psychosocial functions were found to be related to satisfaction with the mentor. Furthermore, subjective career success was related to both reception of career and psychosocial functions. However, as discussed by Allen, Eby, and Lentz (2006), little is known regarding the various relationship contingencies that lead to increased provision/reception of these functions. In turn, little guidance is available for maximizing the effectiveness of mentoring relationships and/or programs. 


\section{Satisfaction with the Mentoring Relationship}

Satisfaction with the mentoring relationship has been found to be related to various relationship and individual disposition variables. For example, mentors tend to be more satisfied with their protégés when their protégés are open to coaching and advisement (Young \& Perrewe, 2000), individuals participating in informal mentoring relationships tend be more satisfied than those participating in formal programs (likely due to extraneous factors, such as length of relationship), and individuals who perceive themselves to be more similar are more likely to report higher relationship satisfaction (Allen \& Eby, 2003). Moreover, it has been found to be related to various other outcomes, such as relationship duration (Rhodes, Lowe, Litchfield, \& Walsh-Samp, 2008). Thus, satisfaction with the mentoring relationship is likely an important subjective outcome of mentoring relationship processes.

\section{Subjective versus Objective Indicators}

As generally well accepted, perceptions are oftentimes biased or can easily differ from person to person (e.g., O’Reilly, Parlette \& Bloom, 1980; Smith-Jentsch, Salas, \& Brannick, 2001). Specifically, although there is likely some grain of truth in perceptions, oftentimes our frame of reference (which can be affected by numerous issues, such as past experience) affects the manner in which we interpret the stimuli around us. For example, there has been a great deal of research that has demonstrated that individuals can be ambivalent of information that is inconsistent with their beliefs, and that individuals are likely to interpret ambiguous information as consistent with their beliefs (e.g., Marsh, Cook, \& Hicks, 2006; Snyder \& Uranowitz, 1978; Sulin \& Dooling, 1974).

It is likely that mentors and protégés have different conceptualizations of what is expected from them during the course of the relationship - and subsequently perceive the effectiveness of the relationship differently. Obtaining an understanding of the communication processes that lead to subjective reports may prove valuable for future preparatory training initiatives or program structuring. In order to do this, an analysis of the relations of several indicators from the LIWC in regards to our effectiveness criteria (i.e., psychosocial support, academic career support, and mentoring relationship satisfaction reports, and the average of these three indices) was conducted.

\section{METHODS}

\section{Participants}

There were 72 mentors and protégés from a large Southeastern university that volunteered to participate in this study. Mentors consisted of juniors/seniors with a minimum GPA of 3.0, and protégés consisted of incoming freshmen. Mentors were only paired with one protégé, and vice versa. Participants were recruited through a variety of means, including flyers, and classroom recruitment, email, and honor society recruitment (mentors only). Protégés had a mean age of 18 years, and consisted of 18 males and 54 females. Mentors had a mean age of 24, and consisted of 17 males and 55 females. Moreover, majors at the university were well represented, with protégés coming from 37 majors and mentors from 27 different majors.

\section{Measures}

Both self-report measures and coded behavioral processes were used in this study to obtain a better understanding of the accuracy of perceptions and the various communication processes that affect these perceptions. Perceptions of psychosocial support and career support functions, communication indicators of the LIWC, and mentoring relationship satisfaction were assessed.

\section{$L I W C$}

The LIWC program provides word count percentages for 76 different categories of communication. The various categories were reviewed, and those categories that appeared to assess psychosocial related communication (social processes, affective processes, home, and assent), and academic career support processes (cognitive processes, work, achievement, and money) were selected. The social, affective and 
cognitive indicators have several sub-indices, but the overall categories were only used to minimize family-wise error. Home, work, achievement, and money were subcategories from the personal concerns category (no overarching variable was available for this category), and assent was selected from the spoken categories. Specifically, the overarching categories of social processes and cognitive processes were included, in addition to each of the personal concerns variables. This resulted in 8 LIWC indicators (See Table 1 for selected communication indices).

\section{TABLE 1 \\ PSYCHOSOCIAL AND ACADEMIC/CAREER SUPPORT INDICATORS FROM LIWC}

\begin{tabular}{|c|c|}
\hline \multicolumn{2}{|c|}{ LIWC Indicators Selected } \\
\hline Psychosocial-Related Indicators & \\
\hline Social Processes & Academic/Career Support Related Indicators \\
Example words: & Cognitive processes \\
Mate, talk, they, child & Example Words: \\
Affective processes & cause, know, ought \\
Example Words: & Work \\
happy, cried abandon & Example Words: \\
Home & job, majors, Xerox \\
Example Words: & Achievement \\
apartment, kitchen, family & Example Words: \\
Assent & earn, hero, win \\
Example Words: & Money \\
agree, OK, yes & Example Words: \\
& audit, cash, owe \\
\hline
\end{tabular}

Psychosocial and Career Support/Functions Given/Received

Allen, McManus, \& Russell's (1999) mentoring functions scale was used to assess perceptions of the amount of psychosocial and career support functions that had been provided during the course of the mentoring relationship. This scale consisted of 25 items (14 to assess psychosocial support and 11 to assess career support), and used a 6-point Likert (1 strongly disagree to 6 strongly agree), and was collected after completion of the mentoring sessions. Items were identical for protégés and mentors, except that the questions were designed to reflect whether each question was from the mentor or protégé perspective. For example, a career support item for protégés read "My mentor reduced unnecessary risks that could threaten the possibility that I would advance through my program of study", whereas the mentor item was "I helped reduce unnecessary risks that could threaten the possibility that my protégé would advance through his/her program of study". For psychosocial support, an example protégé item was "My mentor discussed my questions and concerns regarding feelings of competence": whereas the mentor item was "I discussed my protégé's questions and concerns regarding feelings of competence". This scale resulted in an alpha coefficient of .92 for both mentors and protégés.

\section{Satisfaction with the Mentoring Relationship}

The Allen and Eby (2003) self-report scale was collected from both mentors and protégés. The scale consisted of 6 items, (rated 1 strongly disagree to 6 strongly agree). Items were again identical for mentors and protégé, except reworded respectively. A sample item from the mentor perspective was "The mentoring relationship between my protégé and I was very effective", and another sample item from the 
protégé perspective was "I am satisfied with the relationship that developed between my mentor and myself". This scale obtained an alpha coefficient of .97 for protégés, and .96 for mentors.

\section{Procedures}

Mentors and protégés were first paired with one another, based upon their availability for mentoring sessions. Participants were informed not to disclose personal information (i.e., last name, email address, nor phone number) to prevent them from communicating with one another outside of the control of the mentoring program. Partners met with one another, online, once a week (30 minutes each session) for four consecutive weeks. Once participants completed the four formal sessions, they filled out measures assessing their perceptions of the effectiveness of the relationship.

\section{RESULTS}

Intercorrelations, means, and standard deviations of the subjective indicators (perceptions of psychosocial and academic/career support relayed, and mentoring relationship satisfaction) for both mentors and protégés are reported in Table 2. Coefficient alphas for scale items are reported in the diagonal. The relations within individual were relatively high - for mentors values ranged from .56-.72 and for protégés from .71-.74. Thus, these scales appear to be assessing a similar overarching construct. In turn, these three indicators were averaged to form an overall effectiveness evaluation indicator. Interestingly, mentor and protégé reported satisfaction was related $(r=.28)$, and the overall effectiveness averages for both $(r=.21)$, indicating that there was some consistency in perceptions.

TABLE 2

INTER-CORRELATIONS OF SUBJECTIVE REPORTS OF RELATIONSHIP EFFECTIVENESS

\begin{tabular}{|c|c|c|c|c|c|c|c|c|}
\hline Variables & $M$ & $S D$ & 1 & 2 & 3 & 4 & 5 & 6 \\
\hline $\begin{array}{l}\text { 1. Protégé-Reported } \\
\text { Psychosocial Support } \\
\text { Received }\end{array}$ & 4.87 & 0.80 & .92 & & & & & \\
\hline $\begin{array}{l}\text { 2. Protégé-Reported } \\
\text { Academic/Career } \\
\text { Support Received }\end{array}$ & 4.02 & 1.03 & $.74 * *$ & .92 & & & & \\
\hline 3. Protégé satisfaction & 5.07 & 1.13 & $.73 * *$ & $.71 * *$ & .97 & & & \\
\hline $\begin{array}{l}\text { 4. Mentor-Reported } \\
\text { Psychosocial Support } \\
\text { Given }\end{array}$ & 4.64 & 0.70 & .13 & .15 & .10 & .86 & & \\
\hline $\begin{array}{l}\text { 5. Mentor-Reported } \\
\text { Academic/Career } \\
\text { Support Given }\end{array}$ & 3.74 & 0.99 & .01 & .19 & .11 & $.72 * *$ & .86 & \\
\hline 6. Mentor Satisfaction & 4.88 & 1.13 & .16 & $.28 *$ & $.29 *$ & $.61 * *$ & $.56 * *$ & .96 \\
\hline
\end{tabular}

Notes: Bolded values are significant one-tailed at .05 , values marked by * are significant two-tailed at .05 , and values marked by ** are significant two-tailed at .01. Sample sizes vary between 69 and 72. Alpha coefficients are reported in the diagonal.

For the first hypothesis, it was proposed that mentors and protégés would mirror one another's behaviors. As indicated in Table 3, correlations ranged from .28 to .55 for mentor and protégé indicators for the various communication indices examined. Thus, this proposition was supported. 
For the next analysis, we were interested in understanding which of these process variables related to mentor and protégé-reported relationship effectiveness. Correlations of these process variables with our three subjective indicators, psychosocial support relayed, academic/career support relayed, and mentoring relationship satisfaction, in addition to the overall average created from these three measures. These variables were also separated based on our initial conceptualizations of which categories should be related to psychosocial and academic/career related conversations - however, given the relations of the two selfreports, in many cases communication processes tended to be related to both if related to one.

\section{TABLE 3 \\ MENTOR AND PROTÉGÉ RECIPROCITY OF COMMUNICATION}

\begin{tabular}{|c|c|}
\hline \multicolumn{2}{|c|}{ Reciprocity of Mentor and Protégé Communications } \\
\hline Psychosocial-Related Indicators & \\
\hline Social Processes & Academic/Career Support Related Indicators \\
$r=.28, p=.018$ & Cognitive processes \\
Affective processes & $r=.41, p<.001$ \\
$r=.49, p<.001$ & Work \\
Home & $r=.54, p<.001$ \\
$r=.49, p<.001$ & Achievement \\
Assent & $r=.32, p=.007$ \\
$r=.55, p<.001$ & Money \\
\end{tabular}

Note: Significance values reported are two-tailed. Sample sizes vary between 69 and 72.

\section{Mentor Communications}

First, the relations of mentor communications in regards to mentor and protégé reports of relationship effectiveness were examined. These correlations are presented in Table 4. Mentor affectrelated and assent communication indices were positively related to protégés' overall evaluations, perceptions of psychosocial support received, and satisfaction. However, none of these indicators related to protégé perceived academic support received. For mentor reports, social process, cognitive process, and achievement communications were positively related to overall evaluations. Surprisingly, mentor assent communications was approaching statistical significance for being negatively related for mentors' overall evaluations - whereas it was positively related for protégés' perceptions.

\section{Protégé Communications}

Then, the relations protégé communications in regards to mentor and protégé reports of relationship effectiveness were examined. These correlations are presented in Table 5. Protégés' overall effectiveness indicator was related to assent, whereas affective processes and work were approaching statistical significance (based on two-tailed tests since this was an exploratory analysis). 


\section{TABLE 4 \\ MENTOR COMMMUNICATIONS AND MENTOR/PROTÉGÉ REPORTS OF RELATIONSHIP EFFECTIVENESS}

\begin{tabular}{|c|c|c|c|c|c|c|c|c|c|c|}
\hline \multirow[b]{2}{*}{$\begin{array}{c}\text { Mentor } \\
\text { Communication } \\
\text { Variables }\end{array}$} & \multirow[b]{2}{*}{$M$} & \multirow[b]{2}{*}{$S D$} & \multicolumn{4}{|c|}{ Protégé Reports } & \multicolumn{4}{|c|}{ Mentor Reports } \\
\hline & & & 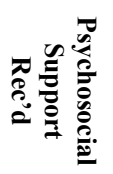 & 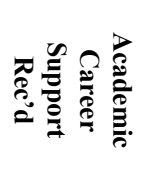 & 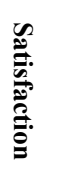 & 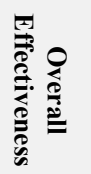 & 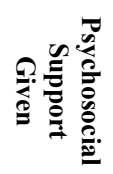 & 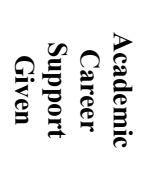 & 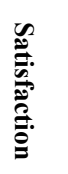 & 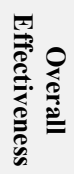 \\
\hline \multicolumn{11}{|l|}{$\begin{array}{l}\text { Psychosocial } \\
\text { Indicators }\end{array}$} \\
\hline $\begin{array}{l}\text { Social } \\
\text { Processes }\end{array}$ & 5.70 & 1.21 & .11 & .13 & .01 & .09 & $.33 * *$ & $.36 * *$ & .11 & $.28 *$ \\
\hline $\begin{array}{l}\text { Affective } \\
\text { Processes }\end{array}$ & 3.70 & 0.79 & $.30 *$ & .19 & $.26 *$ & $.27 *$ & -.02 & -.01 & .00 & -.01 \\
\hline Home & 0.19 & 0.14 & -.03 & -.13 & -.11 & -.11 & .13 & -.04 & .02 & .04 \\
\hline Assent & 1.24 & 0.58 & .21 & .19 & .23 & .23 & -.17 & $-.25 *$ & -.10 & -.19 \\
\hline \multicolumn{11}{|l|}{$\begin{array}{c}\text { Academic/ } \\
\text { Career Support } \\
\text { Indicators }\end{array}$} \\
\hline $\begin{array}{l}\text { Cognitive } \\
\text { Mechanisms }\end{array}$ & 8.14 & 1.61 & .01 & .05 & .06 & .05 & .21 & $.33 * *$ & .20 & $.28 *$ \\
\hline Work & 2.79 & 0.66 & .12 & .17 & -.01 & .10 & .03 & $.29 *$ & -.03 & .10 \\
\hline Achievement & 0.86 & 0.27 & -.03 & .01 & .07 & .03 & .22 & $.34 * *$ & .18 & $.28 *$ \\
\hline Money & 0.26 & 0.14 & -.02 & -.04 & -.12 & -.07 & .04 & .10 & .07 & .09 \\
\hline
\end{tabular}

Notes: Bolded values are significant one-tailed at .05 , values marked by * are significant two-tailed at .05, and values marked by ** are significant two-tailed at .01. Sample sizes vary between 69 and 72 .

Protégé affective processes related to psychosocial support perceptions, and work communications related to perceptions of psychosocial and academic/career support perceptions. Assent also related to our three individual indicators. In regards to mentor reports, the overall relationship effectiveness average related to protégés cognitive process and work communications. Cognitive processes and work communications also related to academic/career support perceptions. Interestingly, none of the protégé communication variables were related to mentor relationship satisfaction. 


\section{TABLE 5 \\ PROTÉGÉ COMMUNICATIONS AND MENTOR/PROTÉGÉ REPORTS OF RELATIONSHIP EFFECTIVENESS}

\begin{tabular}{|c|c|c|c|c|c|c|c|c|c|c|}
\hline & & & & Protégé $\mathrm{R}$ & ports & & & Mentor Rep & & \\
\hline $\begin{array}{c}\text { Protégé } \\
\text { Communication } \\
\text { Variables }\end{array}$ & $M$ & $S D$ & 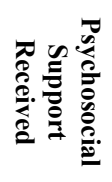 & 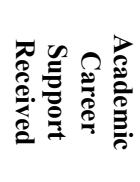 & 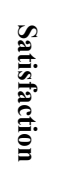 & 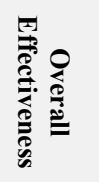 & 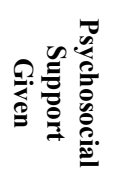 & 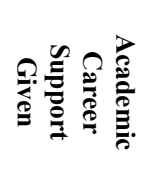 & 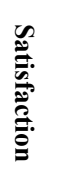 & 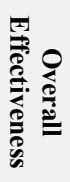 \\
\hline $\begin{array}{l}\text { Psychosocial } \\
\text { Indicators }\end{array}$ & & & & & & & & & & \\
\hline Social Processes & 3.93 & 1.02 & .11 & -.14 & -.05 & -.05 & .01 & -.08 & $\begin{array}{c}- \\
.09\end{array}$ & -.06 \\
\hline Affective Processes & 3.50 & 0.92 & $.24^{*}$ & .20 & .19 & .23 & .02 & -.03 & .05 & .03 \\
\hline Home & 0.18 & 0.11 & .12 & -.11 & -.06 & -.03 & -.04 & -.13 & $\begin{array}{c}- \\
05\end{array}$ & -.08 \\
\hline Assent & 1.76 & 0.68 & $.33^{* *}$ & $.26^{*}$ & $.35^{*}$ & $.34 * *$ & .09 & -.04 & .18 & .10 \\
\hline $\begin{array}{c}\text { Academic/ } \\
\text { Career Support } \\
\text { Indicators }\end{array}$ & & & & & & & & & & \\
\hline Cognitive Processes & 7.47 & 1.76 & .10 & .03 & .04 & .06 & .23 & $.25^{*}$ & .16 & $.25^{*}$ \\
\hline Work & 2.34 & 0.57 & $.25^{*}$ & $.27^{*}$ & .12 & .23 & .18 & $.27^{*}$ & .16 & $.24 *$ \\
\hline Achievement & 0.63 & 0.24 & .04 & .10 & -.05 & .03 & .13 & .16 & .13 & .17 \\
\hline Money & 0.18 & 0.11 & .07 & -.05 & -.04 & -.02 & .04 & .05 & .13 & .09 \\
\hline
\end{tabular}

Notes: Bolded values are significant one-tailed at .05 , values marked by $*$ are significant two-tailed at .05 , and values marked by ** are significant two-tailed at .01. Sample sizes vary between 69 and 72 .

\section{DISCUSSION}

There still remains a tremendous gap in our understanding of the processes involved in successful mentoring relationships, and subsequently, how to maximize the effectiveness of these relationships. The results of this study have provided some insight into communication processes of mentors and protégés, and how these communications relate to mentor and protégé reports of mentoring relationship effectiveness.

\section{Reactive Nature of Mentoring Relationship Processes}

As contended throughout this manuscript, mentoring relationships are complex, dynamic, interpersonal relationships. In support of this notion, it was found that mentors and protégés tailor their own behaviors in regards to their partner's behaviors - as everyone of our mentor and protégé communication indicators were correlated. This in turn presents many challenges in our attempts to capture the specific processes that lead to more effective mentoring relationships. Given the malleable behavior of individuals in mentoring relationships, this in turn may make it more difficult in some instances when coding for such behaviors, as examining behaviors may require innovative indexing 
methods that take into account what both the mentor and protégé are doing together (rather than just examining for example the protégé average for a specific behavior).

\section{Perceived Mentoring Relationship Effectiveness and Communications}

Consistent with the previous contentions regarding frames-of-reference and subjective inferences, it appears that mentors and protégés use different sources of information when evaluating mentoring relationship effectiveness. Furthermore, although the three indicators of relationship effectiveness (i.e., psychosocial support relayed, academic career support relayed, and satisfaction with the mentoring relationship) were highly related, in some cases different communication processes had distinct relations with these criteria.

For both mentor and protégé communications, it was found emotion-related communications were related to perceived relationship effectiveness for protégés. However, this did not hold for mentors. Thus, it is likely that the most effective mentors may spend more time discussing their emotions and encouraging their protégés to do the same. Discussion of emotions has previously been argued (e.g., Moberg, 2008) to be important to mentoring relationship success - and given our population this type of discussion may be particularly important. Many of the protégés in our program were facing one of the most difficult transitions in their lives - possibly facing their first experience living away from their families, learning how to study, trying to make new friends, and in many cases feeling that they are failing many of the obstacles that have been thrown at them. Consequently, they are likely facing many emotions - and their mentor sharing their past experiences, and discussing their own, may prove quite helpful for protégés.

Mentors discussion of cognitive processes was important for mentor perceptions of relationship effectiveness, but not for protégés. Interestingly, protégé discussion of these variables was also important for mentor reports, but again not at all important for protégé reports. Mentors social discussions appeared important for some of the reports of mentors' perceived effectiveness, but not for protégés' perceptions. Protégés communication of these variables also failed to be related to protégé or mentor reports. As a result, these types of communications are likely of limited utility to mentoring relationship success and should likely be limited.

Mentor work and achievement communications were also important to perceptions of academic/career support relayed for mentors, but not protégés. However, protégé communications of work and achievement were important for protégé perceptions (with only protégé work communications important for mentors). Therefore, an individual's own discussion of these types of communications appears to be more related to his/her perceptions of effectiveness.

Assent communications were somewhat contradictory - as mentors who agreed with their protégés felt that they provided less career support. However, this was a positive variable for protégés - thus, it may be beneficial to train mentors that assenting communications will be favorably received by the protégés (although they may not feel as comfortable with doing so). Moreover, the mentor agreeing with the protégé may prove as a source of support, or possibly an indicator of similarity of thought processes. Past research has repeatedly found that similarity is related to perceptions of mentoring relationship effectiveness (Ensher, Grant-Vallone, \& Marelich, 2002; Sosik \& Godshalk, 2005) - assent may be an indicator of, or even an antecedent to, perceptions of similarity. Given the effect sizes obtained in this study, this agreement may be the most important communication process of all.

\section{Qualitative Comparison}

Examining the relations of own communications with reports regarding the effectiveness of the mentoring relationship, it appears that individuals own communications tended to have slightly higher/more relations with their reports in many instances than with their partners. Although expected for mentors, this is a bit counter-intuitive at first inspection for protégés. It may be that individuals remember better the issues that they discussed relative to the issues that their partners discussed. However, it is quite plausible that many of the indicators examined may be affected by the level of engagement of the participants in the mentoring relationship. To elaborate, it might be that individuals who feel that the 
relationship is beneficial may attempt to contribute more to the relationship - to ask questions, to be proactive in the relationship, and subsequently feel that the issues discussed were valuable.

\section{Practical Implications}

An important implication based on these results is that it may be possible to use preparatory training to maximize relationship effectiveness. Given the findings regarding reciprocity, by training one individual to communicate a certain way, the other individual will likely follow that individual's lead thus possibly limiting the need to train both mentors and protégés. Furthermore, it is plausible that training mentors regarding assent (e.g., agreeing with the protégé and offering positive acknowledgements), to focus more on discussion of emotions, minimizing their cognitive-related and achievement discussions, may be fruitful for protégés. Similarly, none of the protégé communication indices were related to mentor-reported satisfaction - whereas several of the mentor communication indices were. Thus, mentors may be more tuned into their own behaviors (and perceived effectiveness) when evaluating their satisfaction. It may be valuable to train mentors to focus more on developing a relationship with their protégés - rather than just being an 'effective' mentor to further expand their criteria for evaluating the relationship after-the-fact. Finally, for online programs, it may be valuable to assess the communications during the course of the relationship using such an automatic communication evaluation program like the LIWC program. If individuals are found to be low for some of these indices, then it may be valuable to rematch these dyads early on in the relationship to assure future positive mentoring relationship outcomes.

\section{Limitations and Future Research}

Future research is needed to cross-validate the findings obtained in this study. Given the number of communication indicators selected, there is a high probability of type I error for some of the findings discussed. However, many of the effects were large enough that it is likely that these results will be reproducible. Furthermore, the results of this study are likely limited to similar academic online mentoring programs. Mentoring relationships change greatly over time - thus, a markedly longer program will likely obtain different inferences. Moreover, it is likely that communications will be different if graduate students or faculty members are used as mentors in lieu of juniors and seniors.

Another limitation is that the mentoring relationships in this study occurred through computermediated communication, which may have affected the manner in which individuals behaved. For example, individuals communicating face-to-face may not model their partners' behaviors as much as those communicating through computer-mediated communication. Finally, as the current study design does not allow for inferences regarding direction of causality of the behaviors examined to be determined, future research should attempt to address this gap in our understanding. Although given these limitations, this research represents an important step in understanding communications that occur during mentoring relationships and how these relationships lead to subjective evaluations of the relationship's effectiveness.

\section{Summary}

This study represents an initial step toward better understanding which communication processes that take place in academic mentoring relationships relate to mentoring success. The LIWC program and its related indicators selected for this study revealed that (a) mentors and protégés would mirror one another's communications, (b) mentors and protégés reacted differently in regards to their perceptions of what occurred during the course of the relationship relative to the different communication indicators, and (c) assent communications were positively perceived by protégés, whereas they were negatively perceived by mentors. As a result, this added knowledge of some important processes that occur during mentoring relationships in relation to mentoring outcomes, can help devise better structured mentoring programs by aiming to maximize relationship effectiveness. 


\section{REFERENCES}

Allen, T. D., Eby, L. T., \& Lentz, E. (2006). Mentorship behaviors and mentorship quality associated with formal mentoring programs: Closing the gap between research and practice. Journal of Applied Psychology, 91(3), 567-578.

Allen, T. D., Eby, L. T., Poteet, M. L., Lentz, E., \& Lima, L. (2004). Career benefits associated with mentoring for protégés: A meta-analysis. Journal of Applied Psychology, 89(1), 127-136.

Allen, T. D., McManus, S. E., \& Russell, J. E. A. (1999). Newcomer socialization and stress: Formal peer relationships as a source of support. Journal of Vocational Behavior, 54, 453-470.

Alvarez, A. N., Blume, A. W., Cervantes, J. M., \& Thomas, L. R. (2009). Tapping the wisdom tradition: Essential elements to mentoring students of color. Professional Psychology: Research and Practice, 40(2), 181-188.

Bandura, A. (1977) Social Learning Theory. New Jersey: Prentice Hall.

Bernstein, E. (1967). Sources of cognitive bias in the representation of simple social structures: balance, minimal change, positivity, reciprocity, and the respondent's own attitude. Journal of Personality and Social Psychology, 7(1), 36-48.

Burney, J. P., Celeste, B. L., Davis Johnson, J., Klein, N. C., Nordal, K. C., \& Portnoy, S. M. (2009). Mentoring professional psychologists: Programs for career development, advocacy, and diversity. Professional Psychology: Research and Practice, 40(3), 292-298.

Brown, R. T., Daly, B. P., \& Leong, F. T. L. (2009). Mentoring in research: A developmental approach. Professional Psychology: Research and Practice, 40(3), 306-313.

Campbell, C. D. (2007). Best practices for student-faculty mentoring programs. In T. D. Allen \& L. T. Eby (Eds.), The Blackwell handbook of mentoring: A multiple perspectives approach. Malden, MA: Blackwell.

Chao, G. T., Walz, P. M., \& Gardner, P. D. (1992). Formal and informal mentorships: A comparison on mentoring functions and contrast with nonmentored counterparts. Personnel Psychology, 45, 619-636.

D’Abate, C. P. D. \& Eddy, E. R. (2008). Mentoring as a learning tool: Enhancing the effectiveness of an undergraduate business mentoring program. Mentoring and Tutoring: Partnership in Learning, 16(4), 363-378.

Derlega, V. J., Wilson, M., \& Chaikin, A. L. (1976). Friendship and disclosure reciprocity. Journal of Personality and Social Psychology, 34(4), 578-582.

Durkin, K. \& Main, A. (2002). Discipline-based study skills support for first-year undergraduate students. Active Learning in Higher Education, 31(1), 24-39.

Ensher, E. A., Grant-Vallone, E. J. \& Marelich, W. D. (2002). Effects of perceived attitudinal and demographic similarity on protégés' support and satisfaction gained from their mentoring relationships. Journal of Applied Social Psychology, 32(7), 1407-1430. 
Evans, G. L. \& Cokley, K. O. (2008). African American women and the academy: Using career mentoring to increase research productivity. Training and Education in Professional Psychology, 2(1), 50-57.

Fagenson, E. A. (1989). The mentor advantage: Perceived career/job experiences of protégés versus nonprotégés. Journal of Organizational Behavior, 10, 309-320.

Garone, E. (2009). Pile on mentors in tough times. Wall Street Journal - Eastern Edition, 82, 6.

Hendrickson, B. \& Goegi, R. (2009). Reciprocity and dating: Explaining the effects of favor and status on compliance with a date request. Communication Research, 36(4), 585-608.

Nguyen, A. M. D., Huynh, Q. L., \& Lonergan-Garwick, J. (2007). The role of acculturation in the mentoring career satisfaction model for Asian/Pacific Islander American university faculty. Cultural Diversity and Ethnic Minority Psychology, 13, 295-303.

Johnson, W. B. (2008). Are advocacy, mutuality, and evaluation incompatible mentoring functions? Mentoring \& Tutoring: Partnership in Learning, 16(1), 31-44.

Kanter Agliata, A. \& Renk, K. (2009). College students' affective distress: The role of expectation discrepancies and communication. Journal of Child and Family Studies, 18, 396-411.

Kram, K. E., \& Isabella, L. A. (1985). Mentoring alternatives: The role of peer relationships in career development. Academy of Management Journal, 28, 110-132.

Marsh, R. L., Cook, G. I., \& Hicks, J. L. (2006). Gender and orientation stereotype bias sourcemonitoring attributions. Memory, 14, 148-160.

Moberg, D. J. (2008). Mentoring for protégé character development. Mentoring \& Tutoring: Partnership in Learning, 16(1), 91-103.

O'Carroll Bantum, E. \& Owen, J. E. (2009). Evaluating the validity of computerized content analysis programs for identification of emotional expression in cancer narratives. Psychological Assessment, 21(1), 79-88.

O'Reilly, C. A., Parlette, G. N., \& Bloom, J. R. (1980). Perceptual measures of job characteristics: The biasing effects of differing frames of reference and job attitudes. Academy of Management Journal, 23, $118-131$.

Pennebaker, J. W. (1997). Writing about emotional experiences as a therapeutic process. Psychological Science, 8, 162-166.

Pennebaker, J. W., Chung, C. K., Ireland, M., Gonzales, A. L., \& Booth, R. J. (2007). The development and psychometric properties of LIWC2007. Austin, TX: LIWC.net.

Pennebaker, J. W., \& Francis, M.E. (1996). Cognitive, emotional, and language processes in disclosure. Cognition and Emotion, 10, 601-626.

Powell, R. S. \& O’Neal, E. C. (1976). Communication feedback and duration as determinants of accuracy, confidence, and differentiation in interpersonal perception. Journal of Personality and Social Psychology, 34(4), 746-756. 
Roberts, A. (2000). Mentoring revisited: A phenomenological reading of the literature. Mentoring \& Tutoring, 8(2), 145-170.

Rhodes, J., Lowe, S. R., Litchfield, L. \& Walsh-Samp, K. (2008). The role of gender in youth mentoring relationship formation and duration. Journal of Vocational Behavior, 72, 183-192.

Smith-Jentsch, K. A., Salas, E., \& Brannick, M. T. (2001). To transfer or not to transfer? Investigating the combined effects of trainee characteristics, team leader support, and team climate. Journal of Applied Psychology, 86(2), 279-292.

Sosik, J. J. \& Godshalk, V. M. (2005). Examining gender similarity and mentor's supervisory status in mentoring relationships. Mentoring \& Tutoring: Partnership in Learning, 13(1), 39-52.

Synder, M., \& Uranowitz, S. W. (1978). Reconstructing the past: Some cognitive consequences of person perception. Journal of Personality and Social Psychology, 36, 941-950.

Stephenson, G. M., Laszlo, J., Ehmann, B., Lefever, R. M., \& Lefever, R. (1997), Diaries of significant events: Socio-linguistic correlates of therapeutic outcomes in patients with addiction problems. Journal of Community and Applied Social Psychology, 7, 389-411.

Sulin, R. A., \& Dooling, D. J. (1974). Intrusion of a thematic idea in the retention of prose. Journal of experimental Psychology, 103, 255-262.

Vanheule, S., Desmet, M. \& Meganck, R. (2009). What the heart thinks, the tongue speaks: A study on depression and lexical choice. Psychological Reports, 104(2), 473-481.

Young, A. M., \& Perrewe, P. L. (2000). What did you expect? An examination of career-related support and social support among mentors and protégés. Journal of Management, 26, 611-632. 